\title{
REPORT OF THE COMMITTEE FOR SPERMATOPHYTA
}

\author{
Conservation of Generic Names, IX
}

Rogers McVaugh, Secretary *

The previous report in this series was published in Taxon 17: 85-87. 1968. The present report was prepared by the Committee whose members are listed below, except that Prof. J. Léonard was compelled by pressure of other duties to resign from the Committee at the end of 1967, and took no part in the balloting on these proposals.

A. R. Pinto da Silva, Chairman (Portugal)

R. C. Bakhuizen van den Brink (Netherlands)

G. Buchheim (United States)

A. A. Bullock (England)

F. R. Fosberg (United States)

Hiroshi Hara (Japan)

Nils Hylander (Sweden)

J. Léonard (Belgium)

I. A. Linczevski (U.S.S.R.)

Rogers McVaugh, Secretary (United States)

R. D. Meikle (England)

C. G. G. J. van Steenis (Netherlands)

\section{Reports on proposals for conservation}

As in previous reports, the votes for and against each proposal are shown in parenthesis immediately after the names involved; the affirmative votes precede the negative. Eight affirmative votes were required for a recommendation by the Committee to accept a proposal.

280. Danthonia Lamarck \& De Candolle (1805) vs. Sieglingia Bernhardi (1800). (2-9)

(Regn. Veg. 40: 20. 1965).

The Committee agrees that the name Danthonia should be conserved, but the present proposal is inacceptable. The proposed lectotype, $D$. provincialis, might be acceptable as a species, but the name is illegitimate and the type of the name provincialis (that is, the type of Avena calycina Vill.) is a specimen presumably of hybrid origin. Furthermore another species, Danthonia spicata, was designated as lectotype as early as 1914 , and has been treated as the type of the name Danthonia in many publications on grasses

* The Herbarium, North University Building, University of Michigan, Ann Arbor, Mich., U.S.A. in the last half-century. The Committee declines to accept this proposal. Any subsequent proposal for the conservation of the name Danthonia should include $D$. spicata as lectotype, or show good reason why another species should be designated.

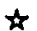

612. Prestoea J. D. Hooker (1883) vs. Martinezia Ruiz \& Pavón (1794) and Oreodoxa Willdenow (1807). (8-2, 1 abstention) (Regn. Veg. 34: 54-55. 1964).

Both Martinezia and Oreodoxa have been wrongly applied to such an extent that they have the status of nomina confusa and it would be unfortunate to take up either one for the genus that has been called Prestoea in recent palm literature. The conservation of Prestoea stabilizes the nomenclature of a group of about 35 species of palms, held to be generically distinct from Euterpe. See the following proposal.

The Committee recommends the conservation of Prestoea, noting however that it is unnecessary to add Euterpe J. Gaertn, to the list of names rejected in favor of Prestoea. Differences in embryo-structure indicate with reasonable certainty that Prestoea Hook. and Euterpe Gaertn. are different genera, even though neither of Gaertner's original species can be positively identified with any known palm.

\section{$\leftarrow$}

631. Euterpe Martius (1837) ys. Euterpe J. Gaertner (1788), Martinezia Ruiz \& Pavón (1794) and Oreodoxa Willdenow (1807). (9-1, 1 abstention) (Regn. Veg. 34: 54. 1964).

The name Euterpe in the sense of Martius has been in general use for more than a century, both in the restricted sense for a genus of about 30 species, and with the broader circumscription that includes Prestoea as well (see the preceding proposal). The present proposal aims to protect Euterpe Mart. against Euterpe Gaertn., of which it is a later homonym (Martius having excluded Euterpe Gaertn. from the genus as he circumscribed 
it). Euterpe Mart. is also to be conserved against Martinezia R. \& P., and Oreodoxa Willd., the types of which are both species of Prestoea, in the event that the genus Euterpe is so broadly construed as to include Prestoea.

The Committee agrees that the conservation of Euterpe Mart. would contribute toward nomenclatural stability. It wishes to point out, however, that the lectotype of Euterpe Gaertn. is properly E. pisifera Gaertn., not E. globosa Gaertn. as stated in the original proposal. $E$. pisifera was indicated (if not explicitly designated) as lectotype by Blume (1843), and Martius (1845), and more explicitly designated by J. D. Hooker (1883).

$$
\text { मे }
$$

1540. Josephia Wight (1851) vs. Josephia R. Brown (1809), Josephia Velloso (1825), Josephia Steudel (1840), Sirhookera Kuntze (1891). (1-10) (Taxon 16: 72. 1967).

The name Sirhookera Kuntze was validly proposed to replace Josephia Wight, the latter being a later homonym. The genus is a small one (2 species), not widely known outside its native country. The name Sirhookera is available and is already at least in limited use by Indian botanists. The Committee feels that the case for conservation of Josephia is not a strong one.

\section{मे}

2551. Decaisnea J. D. Hooker \& Thomson (1854) vs. Decaisnea Brongniart (1829). (101) (Taxon 15: 334. 1966).

The name Decaisnea Hook. \& Thoms. has become relatively widely known because the genus, although small, belongs to the small and morphologically interesting family Lardizabalaceae, and the name has been frequently cited in general botanical works. No other name has been used for the genus and no other name seems to be available. The Committee recommends conservation, noting that although "Slackia Griffith" (1848) was proposed as a nomen rejiciendum it was not validly published and does not need to be considered.

\section{นิ}

3113. Thylachium Lour. corr. A. P. de Candolle (1790) vs. Thilachium (Thilakium) Lour. (1790) and Thylacium Lour, corr.
Spreng. (1790). (2-8, 1 abstention) (Taxon 15: 76. 1966).

This is a proposal to fix the spelling of a generic name in one form that became familiar in the 19th Century, in preference to two differently latinized forms used by the original proposer of the name, and in preference to another competing form established in 1818. It is argued that one or the other of the "corrections" (Thylachium, Thylacium) is etymologically more "correct" than either of the spellings used by Loureiro (Thilachium, Thilakium). There is no strong support for the proposal. The Committee is informed that Loureiro's latinizations were in accordance with Portuguese practice of his time, which aimed at preserving the sounds of Latin letters for Portuguese speakers. The name of the genus was originally spelled Thilachium (Lour. Fl. Cochinch. 342, and index. 1790), but the name of the one species was written Thilakium africanum. In the 1793 editior edited by Willdenow the name was consist ently spelled Thilachium, and the Committee supports the continued use of this form.

\section{मे}

3201. Vahlia Thunberg (1782) vs. Bistella Adanson (1763). (9-2). (Taxon 15: 333. 1966).

The name Vahlia, for a small genus recently (1959) designated as the type of the family Vahliaceae, has been used by all authors since Thunberg until 1966, when Bistella Adans. was revived as the older name for the genus. Vahlia is relatively well-known because the genú is anomalous in the Saxifragaceae where it was often placed, and the name is mentioned in various general works. The Committee feels that to restore Bistella at this time would generate confusion without any compensating benefit, and recommends conservation of Vahlia.

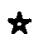

3718. Tephrosia Persoon (1807) (10-0, 1 abstention) (Taxon 16: 73. 1967).

The name Tephrosia is already conserved. This proposal is to add Reineria Moench (Suppl. Meth. Pl. 44. 1802) to list of nomina rejicienda under Tephrosia. The name Reineria has apparently never been adopted since its original publication. The identity of the type and only species can probably never be certainly established, but since the time of 
Moench there has been general agreement that it represented a species of Tephrosia, $T$. reflexa (Moench) DC. The Committee recommends acceptance of this proposal.

\section{मे}

3812. Lourea Desvaux (1813) vs. Lourea J. St.-Hilaire (1812) and Christia Moench (1802). (2-8, 1 abstention) (Regn. Veg. 40: 25. 1965).

The long-accepted name for an Australasian genus of about 15 species was Lourea Necker (1790). Because of the decision at the Montreal Congress to reject the names published in Necker's Elementa Botanica, Lourea is treated as not having been validly published until 1813 (by Desvaux). It is then a later homonym of Lourea J. St.-Hilaire (1812). The oldest available name for the group that has been called Lourea Necker (and Lourea Desvaux) is Christia Moench (1802). This has recently been accepted by several authors, and some of the necessary new combinations have been made. The Committee feels that the conservation of Lourea Desv. at this time would contribute to nomenclatural confusion rather than to stability, and does not wish to accept the proposal.

\section{मे}

3864. Glycine Willdenow (1802) vs. Glycine Linnaeus (1753) (8-2, 1 abstention). (Taxon 15: 35. 1966).

The name Glycine is in general use for a small genus which, as interpreted in the most recent revision of the genus (1962) includes one very important cultivated plant, the soybean. As originally circumscribed by Linnaeus, Glycine included 7 species, none of which constitutes an acceptable lectotype. All but one have for more than a century been regarded as belonging to other genera. The seventh species, $G$. javanica $L$., proves upon examination of the Linnaean type to represent a species of another genus, Pueraria.

It is proposed to conserve the name Glycine from the date of its publication by Willdenow because this treatment includes the oldest valid name of a species that is now generally accepted as a Glycine (G. clandestina Wendl.), and the generic name is at the same time validly published. The Committee recommends the acceptance of the proposal.

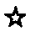

3910. Dolichos Lamarck (1786) vs. Dolichos Linnaeus (1753). (0-11). (Regn. Veg. 40: 26-27. 1965).

The Linnaean Dolichos originally included 12 species, of which only 2 remain in Dolichos even when the genus is accepted in a broad sense. Of these Dolichos lablab L. is generally admitted to be the only acceptable lectotype, and it was formally designated as such at least as early as $\mathbf{1 9 2 4}$.

Since the original publication of Dolichos, 100 or more species have been ascribed to the genus. If this inclusive genus be taxonomically divided, as is now often advocated, the majority of the species fall outside the taxon that includes the type, D. lablab. A group of about 30 species (chiefly African) has become widely known under the name of Dolichos, at the same time the group including $D$. lablab has been referred to the genus Lablab Adans., which name is illegitimate. Another group of about 70 species (chiefly African and Indian) may represent still another distinct genus when Dolichos is construed in the narrow sense.

The alternatives are: 1) Conserve Dolichos Lamarck as proposed. This would provide a name for the largest of the genera resulting from the division of the inclusive Dolichos. It would be a wholly arbitrary typification, as the proposed type (D. uniflorus Lamarck) was not known to Linnaeus, and it would prevent the further use of the name Dolichos Linnaeus even when the genus was broadly circumscribed. It would mean that the illegitimate name Lablab would have to be conserved, or another name provided for that group, and it would mean the creation of new names for additional segregate genera.

2) Continue to recognize Dolichos lablab L. as the type of the generic name Dolichos. This would mean the creation of new generic names if it were thought desirable to recognize the several genera that have been separated from Dolichos sens. str.

3) Typify Dolichos Linnaeus in some other way. It has recently been suggested to the committee that if Dolichos trilobus $\mathrm{L}$. be accepted as type, the number of necessary name-changes would be greatly reduced, there would be no further necessity to conserve Lablab Adans., and it would be possible for those not wishing to divide Dolichos to use the name for the genus in this inclusive sense.

The Committee, recognizing the practical 
necessity of finding an acceptable solution, at the same time feels that the present proposal does not provide such a solution. Any acceptable solution should provide the greatest possible degree of stability in nomenclature, whether or not the genus Dolichos be taxonomically divided. The Committee unanimously expresses its dissatisfaction with the present proposal, and expresses its hope that a better solution may be found. The Committee is somewhat divided in its opinion as to what may be the best way out of the dilemma. There is strong feeling that in this instance it may be best to continue to recognize D. lablab L. as type, simply as a matter of adherence to the principle of priority, even though this may mean the creation of some new generic names. There is also some strong feeling that since the name Dolichos has been used widely for certain large generic groups that do not include the historic type of Dolichos, practicality may dictate the conservation of the name for one such group.

$$
\text { मे }
$$

4244. Thryallis Martius (1829) vs. Thryallis Linnaeus (1762). (10-1). (Taxon 16: 76. 1967).

It is proposed to conserve the name Thryallis for a Brazilian genus of about 3 species. This action would make it possible to use the name Galphimia Cav. (1799), without conservation, even though Galphimia is a synonym of Thryallis Linnaeus. The use of Thryallis Mart. in this sense is in accordance with current practice. If Thryallis Mart. is not conserved, the name Hemsleyna O. Kuntze is available to replace it, but has been little used.

The names Thryallis L. and Galphimia Cav. have both been used, perhaps to about the same extent, for a second tropical American genus, this one of about 10 species.

The Committee feels that it would contribute to a stable nomenclature to fix the name Thryallis (in the sense of Martius) for the smaller genus (to which it is now generally applied), rather than for the larger genus to which the names Galphimia and Thryallis have both been applied to a somewhat confusing extent. The acceptance of this proposal is therefore recommended.

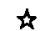

4995. Malvastrum A. Gray (1849), with type M. wrightii vs. Malvastrum A. Gray, with type $M$. coccineum (11-0). (Taxon 15: 311. 1966).

The name Malvastrum has been conserved since 1905 . In $1890 \mathrm{M}$. wrightii was formally proposed as lectotype, but this was overlooked. In $1913 \mathrm{M}$. coccineum was proposed: this species, however, is not a member of the genus Malvastrum as currently interpreted, but a species of Sphaeralcea. The Committee unanimously recommends that reference to $M$. coccineum as the type of the name Malvastrum be removed from the list of Nomina Conservanda, and that it be replaced by $M$. wrightii [M. aurantiacum (Scheele) Walp.].

\section{it}

5256. Warburgia Engler (1895) vs. Chibaca Bertoloni (1853). (8-2), 1 abstention). (Regn. Veg. 40: 27. 1965).

The name Warburgia is well known in East Africa for a genus of 4 species; one species is a very common constituent of upland forest. Chibaca was proposed as a monotypic genus of doubtful affinity, based on fruiting material, and only in 1937 recognized as identical with Warburgia. There seems to be no question that Warburgia and Chibaca are in fact identical, so that Warburgia cannot be used without conservation. As Chibaca has never been taken up in any flora or other work since its first description, the change from Warburgia to Chibaca would merely contribute to synonymy without any compensating benefits. The acceptance of the proposal is recommended.

\section{ฟ}

5384. Eucnide Zuccarini (1845) vs. Microsperma Hooker (1839). (11-0). (Taxon 16: 77. 1967).

Eucnide is a genus of about 11 species, all American. The name has been well known since the monograph of Loasaceae by Urban \& Gilg (1900). In this work the earlier name Microsperma was rejected because it was held to be a homonym of Microspermum Lag. (1816) (Compositae). The Committee holds that in view of some of the examples given in the present Code, and because Microsper$m a$ and Microspermum are in different families, they may not (at least in the opinion of some botanists) be homonyms. Under these circumstances Microsperma would supplant Eucnide. In order to avoid possible future 
embarrassment and confusion, the Committee unanimously recommends the conservation of Eucnide.

$$
\text { is }
$$

6505. Crawfurdia Wallich (post Aug 1826) vs. Tripterospermum Blume (Jul-Dec 1826). (1-10). (Taxon 16: 78. 1967).

The Committee declines to recommend the conservation of Crawfurdia, feeling that the case is less compelling than the proposal would indicate. There is some evidence that the use of the name Tripterospermum is more general than suggested in the proposal. Recent specialists in the Gentianaceae have tended to reinstate Tripterospermum as a valid genus distinct from Crawfurdia, and to reduce some or all species of Crawfurdia sens. str. to Gentiana. The conservation of Crawfurdia as proposed is unnecessary if Tripterospermum is considered to be a genus distinct from Crawfurdia, and also if Crawfurdia is included in Gentiana sens. str. It may be desirable only if Crawfurdia is maintained in the classical sense for all gentians for twining stems; this view is not supported by recent taxonomic opinion.

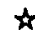

7421. Goetzea Wydler (1830) vs. Goetzea Reichenbach (1828). (8-2, 1 abstention). (Taxon 15: 167, 1966).

The name Goetzea Wydler has been in uninterrupted use since 1830 for a small but anomalous group of species; the genus was recently (1965) made the type of the family name Goetzeaceae. As the name Goetzea Reichenbach was somewhat ambiguously proposed, as it has never been used except by the original proposer and is generally regarded as a synonym on taxonomic grounds, the Committee feels that it would be unfortunate if the name Goetzea Wydler were to be displaced by it. The acceptance of this proposal is therefore recommended.

\section{古}

8874. Lagenophora Cassini (1818) vs. Lagenifera Cassini (1815). (4-6, 1 abstention). (Taxon 15: 75. 1966).

Cassini originally published the name of a genus as Lagenifera, then 3 years later changed it to Lagenophora, a form that has since been universally used. It may be argued 1) That Cassini had no right to change the spelling of a validly published name, or 2) That he never accepted the earlier spelling and in 1818 merely corrected his own error. There is no strong support for the proposal, and the divided vote apparently reflects the opinion that as no new combinations are involved when the spelling of the generic name is corrected, conservation of one spelling so much like another does not seem desirable or necessary.

\section{Summary}

The Committee recommends the conservation of the following names as proposed: 612. Prestoea, 631. Euterpe, 2551. Decaisnea, 3201. Vahlia, 3864. Glycine, 4244. Thryallis, 5256. Warburgia, 5384. Eucnide, 7421. Coetzea. It recommends the proposed changes in the citations of the conserved names 3718 . Tephrosia and 4995. Malvastrum. It does not support the proposals for conservation of 280 . Danthonia, 1540. Josephia, 3113. Thylachium, 3812. Lourea, 3910. Dolichos, 6505. Crawfurdia, 8874. Lagenophora.

\section{GENERAL COMMITTEE ON BOTANICAL NOMENCLATURE}

The attention of all botanists is drawn to the publication of the IXth report of the Committee on Spermatophyta in this issue of Taxon (pp. 325-329). The general Committee will study this report and take a decision on 1 December 1968. Comments and proposals concerning the report should reach the secretary of the General Committee (Mr. R. Ross, Botany Department, British Museum (Natural History), Cromwell Road, London S.W. 7, England) before 1 November 1968.

\section{Nomina conservanda}

The General Committee has approved the proposal by the Committee for Spermatophyta to conserve the following names (for details see the Committee's seventh report, Taxon 16: 226-229. 1967): 668. Astrocaryum, 730 Montrichardia, 752 Alocasia, sub 2542 Naravelia, sub 3197 Lithophragma, 4074 Sargentia, 4302 Glochidion, 4868 Berchemia, 8969 Filago, 9009 Podotheca and a change in the citation of the name 597 Pigafetta (Blume) Martius ex Beccari, corr. J. D. Hooker.

F. A. Stafleu 